\title{
Effect of High Aluminum Concentration in Water Resources on Human Health, Case Study: Biga Peninsula, Northwest Part of Turkey
}

\author{
Coşkun Bakar • Handan Işın Özışık Karaman • \\ Alper Baba $\cdot$ Fatma Şengünalp
}

Received: 4 November 2009/Accepted: 23 November 2009/Published online: 11 December 2009

(C) Springer Science+Business Media, LLC 2009

\begin{abstract}
Widespread and intense zones of silicified, propylitic, and argillic alteration exist as outcrop around the Biga Peninsula, NW Turkey. Most of the springs in the study area surface out from these altered volcanic rocks. The concentrations of aluminum $(\mathrm{Al})$ in these springs ranged from 13.17 to $15.70 \mathrm{ppm}$ in this region. These high levels of $\mathrm{Al}$ were found to exceed the maximum allowable limits $(0.2 \mathrm{ppm})$ depicted in national and international standards of drinking water quality. Therefore, the effect of high $\mathrm{Al}$ in water resources on human health was evaluated in this research. A total of 273 people aged above 18 years and living in the Kirazli region (whose water supply is from springs emerging from these alteration zones) and in the Ciplak-Halileli region (whose water supply is provided from an alluvium aquifer) were selected as the research group. For this group, a questionnaire was completed that contained questions on descriptive characteristics of
\end{abstract}

\section{Bakar}

Department of Public Health, Faculty of Medicine, Canakkale Onsekiz Mart University, Canakkale, Turkey

e-mail: coskunb@comu.edu.tr

\section{H. I. Ö. Karaman}

Department of Neurology, Faculty of Medicine, Canakkale Onsekiz Mart University, Canakkale, Turkey

e-mail: handanisin@yahoo.com

\author{
A. Baba $(\square)$ \\ Department of Civil Engineering, Engineering Faculty, Izmir \\ Institute of Technology, Izmir, Turkey \\ e-mail: alperbaba@iyte.edu.tr \\ F. Şengünalp \\ Department of Geological Engineering, Engineering and \\ Architecture Faculty, Canakkale Onsekiz Mart University, \\ Canakkale, Turkey \\ e-mail: fsengunalp@comu.edu.tr
}

humans and a Mini-Mental State Examination (MMSE) was administered by the authors using the face-to-face interview technique. A neurological examination was then performed by the neurology specialist as a second-stage investigation. Finally, $10 \mathrm{ml}$ of venous blood samples were obtained from these people as a third-stage analysis to determine the serum Al levels together with vitamin $B_{12}$, folic acid, and thyroidstimulating hormone parameters. The result typically revealed that the MMSE score was less in $31.9 \%$ and there was no statistically significant difference between the two regions. However, the result also showed that neuropathy in the history (including a careful past medical history) was significantly higher in the Kirazli region.

Aluminum ( $\mathrm{Al})$ is found in large amounts in the Earth's crust in the form of various compounds (oxygen, fluorine, silica, etc.). It is very rarely found in its free form in nature. It is found in low amounts in living organisms as an element. In its natural form, bauxite mineral is the main source of $\mathrm{Al}$ and is used in various fields in industry (Nordberg 1993). Al is generally detected in low concentrations in waters that are used for drinking water supply purposes. According to the US Environmental Protection Agency (US EPA), World Health Organization (WHO), and the Turkish Ministry of Health, the maximum Al concentration in the drinking water should not exceed 0.2 ppm (TC: The Official Gazette 2005; WHO 2008).

The earliest study describing $\mathrm{Al}$ as a potential neurotoxic substance was an experimental study that dates back to the early 1900s. In 1965, experiments carried out in rabbits indicated that there could be a relationship between Al and Alzheimer's disease (AD). In 1973, increased cerebral Al levels were reported in AD patients (Flaten 2001). Dialysis encephalopathy observed in patients with 
chronic renal failure in the same period supported these findings (Flaten 2001). In the following years, studies indicated that the brain had a predisposition for Al-induced damage and that consumption of food containing $\mathrm{Al}$ additives or water containing high levels of $\mathrm{Al}$ could play a role in AD development (Solfrizzi et al. 2003).

Epidemiological studies carried out in various parts of the world demonstrated a relationship between the drinking water's $\mathrm{Al}$ levels and $\mathrm{AD}$, dementia, and cognitive damage (Flaten 2001; Molloy et al. 2007; Meyer-Baron et al. 2007). Postmortem studies have found increased cerebral Al levels in disorders, such as; $\mathrm{AD}$, amyotrophic lateral sclerosis and Parkinson's disease (Oteiza et al. 2004).

On the other hand, there are also reports that found no relationship between Al and AD (Flaten 2001). However, different methodologies used in these studies, the multifactorial etiology of $\mathrm{AD}$, cognitive function disorders, dementia, and the difficulties in the diagnosis should be taken into account. In 1996, McLachlan et al. (1996) reported 2.5 times higher $\mathrm{AD}$ risk in patients who were exposed to drinking water containing high levels of $\mathrm{Al}$ in their case-control study on brain autopsies. Results of the scientific studies so far has suggested that being exposed to high levels of $\mathrm{Al}$ for a long time might pose a risk of neurological damage.

Based on these fundamentals, this study was carried out in the Kirazli region of the Biga Peninsula located in the northwest Turkey, in order to evaluate the potential of $\mathrm{Al}$ to influence cognitive functions in the people living in areas where acidic waters with high $\mathrm{Al}$ concentrations are consumed.

\section{Characteristics of the Study Area}

The study was carried out in the Biga Peninsula situated in the northwestern parts of Turkey. Two regions (Kirazlı and Ciplak-Halileli) were selected for this study. The Kirazlı region, located $35 \mathrm{~km}$ from the province of Canakkale, was the main point of concern. The control group, on the other hand, was selected from the inhabitants of the CiplakHalileli region, which is located $30 \mathrm{~km}$ away from the province center and about $5 \mathrm{~km}$ away from the worldrenown ancient city of Troia (Fig. 1).

Biga Peninsula is an active tectonic region. The oldest rock in the study area is Paleozoic-age metamorphic rocks,

Fig. 1 Location of study area

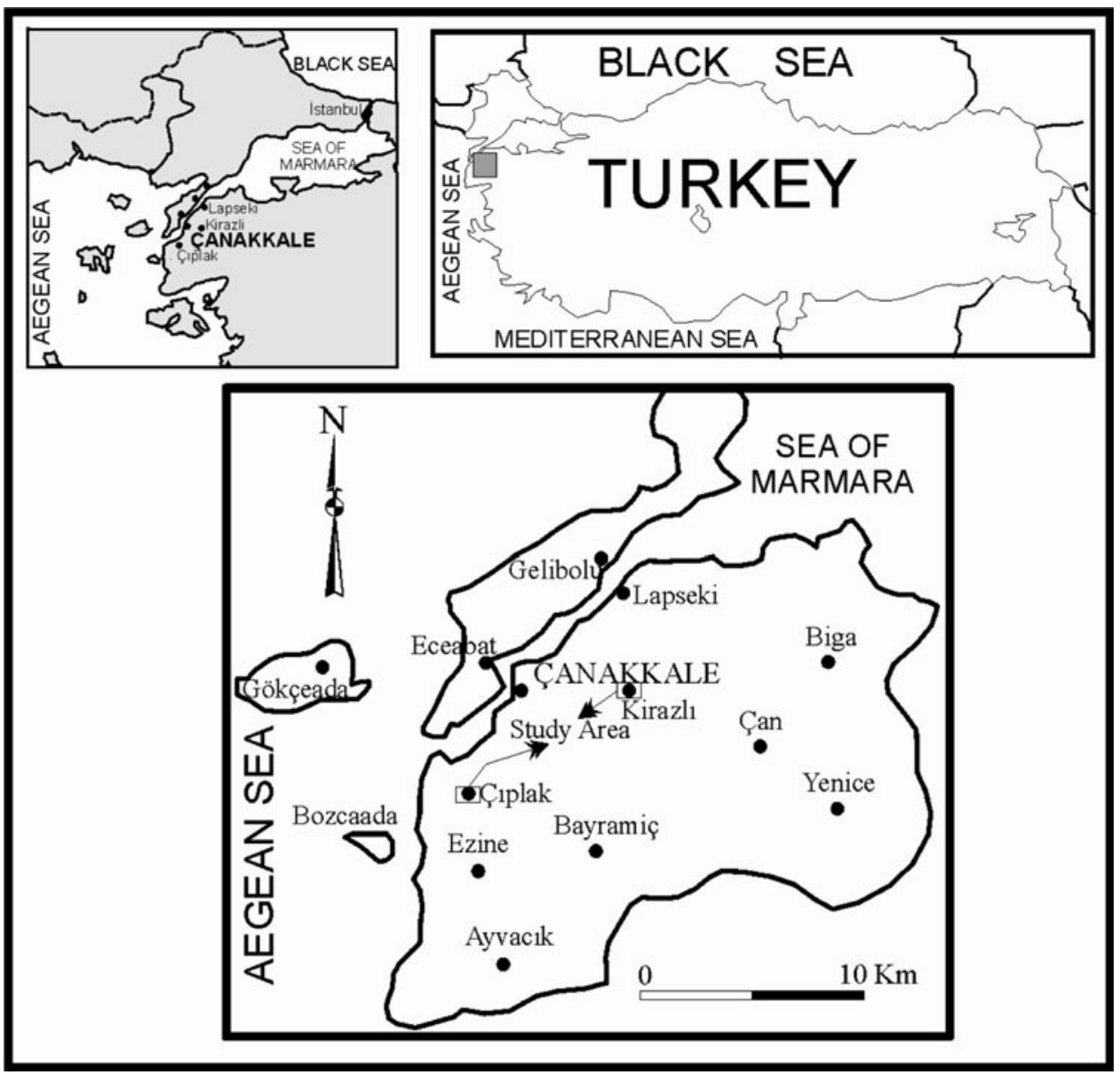


Fig. 2 Regional geology in Biga Peninsula (modified from MTA (2002)

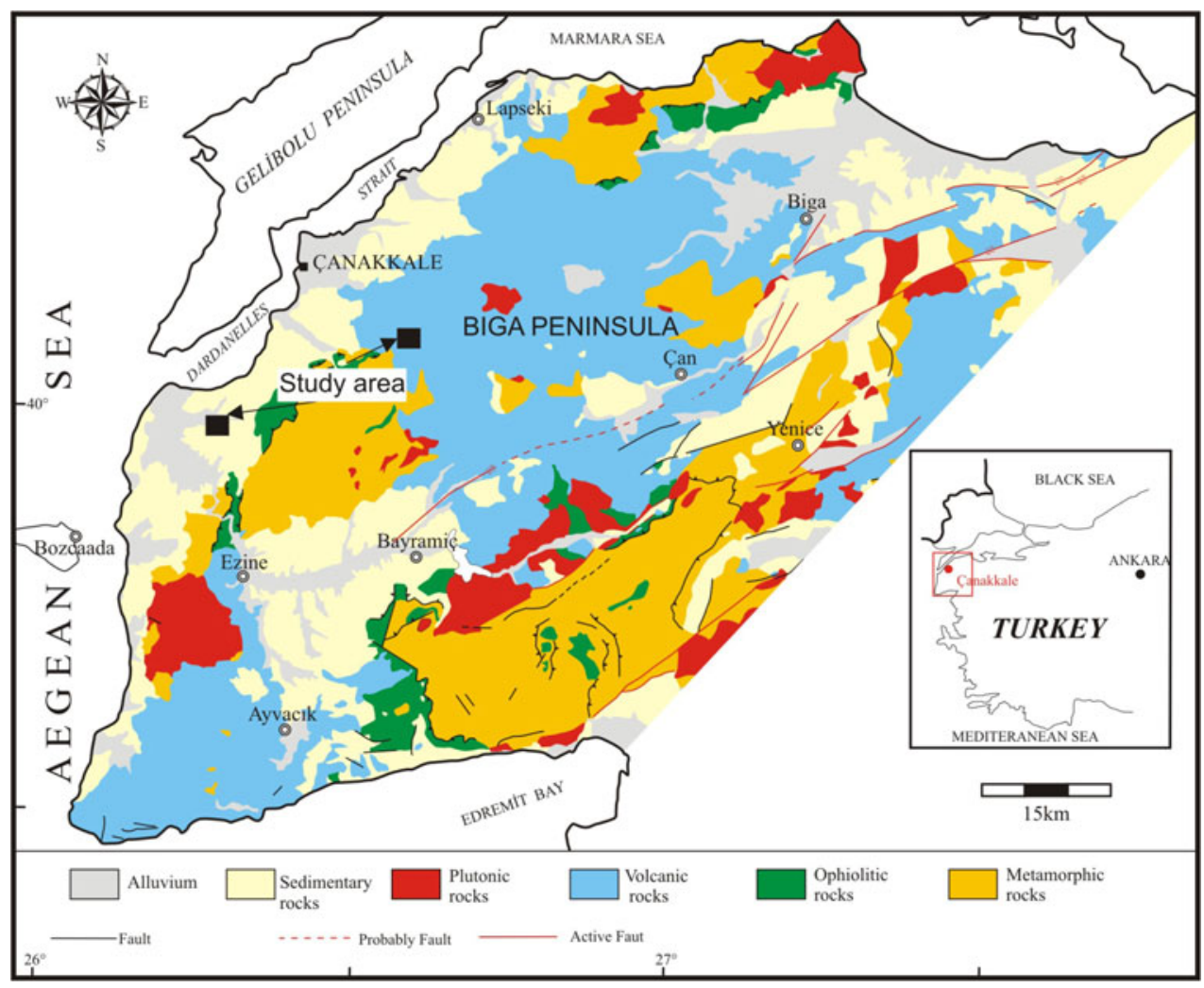

such as schist and marble, which are commonly known as the Kazdag group. Rocks of the so-called Karakaya complex, such as sandstone, shale, ophiolite, and metavolcanics, were settled on this group with a tectonic boundary (Fig. 2). Volcanic and sedimentary rock series cover these units in different parts of the peninsula. Volcanic rocks are the dominant rock types in the region. Most of these rocks are altered and fractured, due to the effects of active faults. Neogene-age sedimentary rocks overlie these rocks. These sediments consist mostly of fine-grained components, such as sand, silt, and clay and might include thick coal veins in different layers. All of the rocks are covered by Quaternary-age alluvium (Baba and Gunduz 2009).

Volcanic rocks of the region generally consist of andesite, basalt, tuff, and agglomerate. Although the volcanic rocks have some water-bearing potential, they do not form good aquifers of regional extent. Nevertheless, their cooling fractures extend several meters in depth, providing a good avenue for deep penetration and circulation of groundwater. Several springs emerge from volcanic rocks in the Biga Peninsula. Altered volcanic outcrops are abundant around the Kirazlı region. The study area is underlain by a sequence of andesitic to dacitic lithic and crystal-lithic tuffs whose primary textures are largely obscured by a blanket of intense silica and clay alteration. Several springs originate from this unit in the study area, as well as in its vicinity. The low $\mathrm{pH}$ values measured in most springs suggest that the groundwater originating from the volcanic areas are affected by mineralization. The Kirazlı region was included in the study, as it has water supplies characterized by high acidic content and Al levels.

Alluvium in the plain has great importance as a medium to hold freshwater and facilitate formation of the water table. The depth of the water table from the surface of the area changes according to seasonal rainfall, but it is not deeper than about $3 \mathrm{~m}$ below the surface, even at the end of the driest summer period. This water can be easily reached and used in many parts of the plain by dug wells. The drinking water requirements of the Ciplak-Halileli region are extracted from this alluvium aquifer. Alluvium, which is most probably derived from sheet wash deposits, fan deposits, coastal and wind-blown sediments, is observed along the flat terrain. It is mostly fine-grained (clay, silt, sand, and conglomerate) and constitutes the major agricultural fields of the study area. Generally, various confined aquifers are observed below the alluvium aquifers. The aquifer has been exploited extensively as a domestic and irrigation water supply source.

\section{Materials and Methods}

The research was designed to be conducted in two phases: The first phase of the study was focused on determining the 
quality of water resources in these two regions. Therefore, water samples were collected and assessed for the drinking water quality. The second phase included the evaluation of cognitive damage, which could be caused by drinking Alcontaining water by the local people living in this region. For this purpose, a total of 273 people who were 18 years of age or older were monitored.

The water samples were analyzed for the presence of any heavy metals and trace elements, including but not limited to Al. One hundred-milliliter water samples were collected from the research area. All samples were then filtered through a $0.45-\mu \mathrm{m}$ filter and stored in polyethylene bottles at $4^{\circ} \mathrm{C}$. The samples were later acidified to $\mathrm{pH}=2$ conditions by adding $0.5 \mathrm{~N} \mathrm{HNO}_{3}$ to prevent complex formation of trace elements with oxygen. Samples were then analyzed by inductively coupled plasma-mass spectroscopy (ICP-MS) at the Canadian ACME Laboratories.

The target population for this research consisted of people living in the Kirazli and Ciplak-Halileli regions, who were 18 years of age or older. There was no sampling group for the study and the aim was to reach everyone aged 18 or older. The population of the Kirazlı region at the time of this study was 201 people (112 males, 89 females) living in 50 households and they were exposed to high levels of $\mathrm{Al}$ in their drinking water. On the other hand, the population of the Ciplak-Halileli region was 921 people (460 males, 461 females) living in 200 households (TSI 2007). Of these totals, 73 people (41 males, 32 females) from the Kirazli region and 164 people ( 89 males, 75 females) from the Ciplak-Halileli region participated this study on a voluntary basis (Table 1). After informing the local people, three surveys were conducted. First, the groups were asked a number of general descriptive questions using a survey form and face-to-face interview technique. Second, a neurology specialist administered a Mini-Mental State Examination (MMSE) and performed a neurological examination in order to determine the group's cognitive performance. Finally, $10 \mathrm{~cm}^{3}$ of venous blood samples from the median cubital vein in the antecubital fossa were collected from each person questioned in order to determine the levels of serum $\mathrm{Al}$, vitamin $\mathrm{B}_{12}$ (which could be a potential dementia cause), folic acid, and thyroid-stimulating hormone (third-generation TSH). The blood taken from the subjects was centrifuged for $5 \mathrm{~min}$ at $3000 \mathrm{rpm}$ in a desktop centrifuge device and the sera were isolated (Young and Bermes 1999). Within the same day, the sera were transported to a laboratory in Istanbul in special boxes containing ice packs to maintain them at a constant temperature of $+4^{\circ} \mathrm{C}$.

The MMSE is a general-purpose cognitive screening test, measuring orientation, language, concentration, configuration praxis, and memory. It consists of 11 sections compiled under five headings: orientation, recording memory, attention and calculation, anamnesis, language; it is assessed based on a scale of 30 points. The cutoff value for the MMSE was taken as 22. Güngen et al. (2002) performed a study in 2002 in order to evaluate the validity and reliability of slight dementia diagnosis seen in the Turkish population.

\section{Laboratory Procedures}

In the sera obtained from the participants of the study, $\mathrm{TSH}$, folic acid, and vitamin $\mathrm{B}_{12}$ were studied using the chemiluminescence enzyme immunoassay method, using the Immulite 2000 Siemens (USA) device, and Al was

Table 1 Concentration of heavy metals in water resources in the study area

\begin{tabular}{|c|c|c|c|c|c|c|c|c|c|}
\hline \multirow[t]{3}{*}{ Metal } & \multirow[t]{3}{*}{ Unit } & \multicolumn{3}{|c|}{ Ciplak-Halileli } & \multicolumn{5}{|l|}{ Kirazli } \\
\hline & & \multicolumn{3}{|c|}{ Groundwater $(\mathrm{CH})$} & \multicolumn{5}{|c|}{ Kirazlı Spring (K) } \\
\hline & & 2008 & 2007 & SD & 2005 & 2006 & 2006 & 2007 & SD \\
\hline $\mathrm{Al}$ & ppm & 0.012 & 0.005 & 0.01 & 13.21 & 15.70 & 13.18 & 13.17 & 1.26 \\
\hline $\mathrm{Ba}$ & $\mathrm{ppb}$ & 112.8 & 92.82 & 14.13 & 22 & 17.83 & 16.28 & 18.71 & 2.42 \\
\hline Co & $\mathrm{ppb}$ & 0.04 & $<.02$ & 0.11 & 20.36 & 21.62 & 16.62 & 19.29 & 2.13 \\
\hline $\mathrm{Cu}$ & $\mathrm{ppb}$ & 2.4 & 10.2 & 5.51 & 6.9 & 22.7 & 3.7 & 2.2 & 9.42 \\
\hline $\mathrm{Fe}$ & $\mathrm{ppb}$ & $<10$ & 12 & 1.41 & 551 & 1123 & 561 & 1174 & 342.73 \\
\hline $\mathrm{Li}$ & $\mathrm{ppb}$ & 1.5 & 5.8 & 3.04 & 10.6 & 11 & 9.4 & 9.2 & 0.89 \\
\hline $\mathrm{Mn}$ & $\mathrm{ppb}$ & 0.7 & 0.25 & 0.32 & 409.22 & 407.41 & 364.53 & 424.73 & 25.83 \\
\hline $\mathrm{Ni}$ & $\mathrm{ppb}$ & $<0.2$ & 4 & 2.69 & 7.2 & 7.9 & 7.2 & 7.6 & 0.34 \\
\hline $\mathrm{Pb}$ & $\mathrm{ppb}$ & 0.9 & 0.7 & 0.14 & 28.8 & 51.2 & 22.6 & 19.2 & 14.39 \\
\hline S & ppm & 18 & 0.013 & 12.72 & 50 & 62 & 42 & 47 & 8.5 \\
\hline $\mathrm{Si}$ & $\mathrm{ppb}$ & 9,515 & 15,016 & 3,890 & 15,518 & 15,516 & 11,774 & 14,064 & 1,767 \\
\hline $\mathrm{Zn}$ & $\mathrm{ppb}$ & 3 & 17 & 9.9 & 77.5 & 82 & 85.1 & 85.1 & 3.59 \\
\hline
\end{tabular}


studied with the atomic absorption spectrophotometry method using a Shimadzu AA-6300 (Japan) device.

\section{Statistical Analysis}

All of the data were evaluated using the SPSS 15.0 software program. Chi-square and Pearson correlation analysis techniques were used in the statistical evaluation and $p<0.05$ was considered as a statistically significant value.

\section{Ethical Considerations}

Participation into the study was performed on a voluntary basis. Permission for the study was taken from the Canakkale Onsekiz Mart University (COMU)-Local Ethics Committee and written approvals of the participants were taken after informing them about the scope of the study.

\section{Results}

The concentrations of some heavy metals such as $\mathrm{Al}, \mathrm{Pb}$, and $\mathrm{Zn}$ are presented in Table 1 . Results show that the $\mathrm{Al}$ concentrations varied between 13.17 and $15.70 \mathrm{ppm}$ in the water resources in the Kirazlı region characterized by fairly acidic content $(\mathrm{pH}<4)$. This value was detected at a relatively higher level than the $\mathrm{Al}$ amount found in the groundwaters of the Ciplak-Halileli region (0.005-0.012) (Table 1). Concentrations of $\mathrm{Al}$ in the water supplies coming from altered volcanic rocks, exceeded the US EPA, WHO, and Turkish drinking water standards, which have a maximum allowable level of $0.2 \mathrm{ppm}$. However, $\mathrm{Al}$ concentrations in the alluvium aquifers, which were used by the local people of the Ciplak-Halileli region, were lower than the recommended limits. The main reason for obtaining high element concentrations in the Kirazlı waters is related to the existence of altered geologic formations, which is consist at more than $80 \% \mathrm{SiO}_{2}, \mathrm{Al}_{2} \mathrm{O}_{3}$, and $\mathrm{Fe}_{2} \mathrm{O}_{3}$ and lower $\mathrm{pH}$ values, compared to the Ciplak-Halileli region waters.

A total of 237 people from both regions were interviewed in this study in order to evaluate the effects of drinking from water supplies containing high $\mathrm{Al}$ levels. The mean age of the subjects was found to be $51.6 \pm 16.3$; $54.9 \%$ were male and $76.8 \%$ were married; $88.6 \%$ of the subjects had an education level of primary school or lower; $13.1 \%$ of those with an education level of primary school and lower were found to be illiterate $(17.7 \%$ females, and $7.5 \%$ males). No difference was detected between the primary descriptive characteristics of the people in both regions $(p>0.05)$ (Table 2).

All of the subjects obtained their drinking water from the groundwater networks in their regions. When asked
Table 2 Demographic properties of the study area

\begin{tabular}{|c|c|c|c|c|c|c|}
\hline & \multicolumn{2}{|c|}{ Kirazli } & \multicolumn{2}{|c|}{ Ciplak-Halileli } & \multicolumn{2}{|l|}{ Total } \\
\hline & $n$ & $\%^{\mathrm{a}}$ & $n$ & $\%^{\mathrm{a}}$ & $n$ & $\%^{\mathrm{a}}$ \\
\hline \multicolumn{7}{|l|}{ Gender } \\
\hline Male & 41 & 56.8 & 89 & 54.3 & 130 & 54.9 \\
\hline Female & 32 & 43.2 & 75 & 45.7 & 107 & 45.1 \\
\hline$p^{\mathrm{b}}$ & \multicolumn{6}{|c|}{0.787} \\
\hline \multicolumn{7}{|l|}{ Age } \\
\hline $19-44$ & 25 & 34.2 & 58 & 35.4 & 83 & 35.0 \\
\hline $45-64$ & 33 & 45.3 & 66 & 40.2 & 99 & 41.8 \\
\hline $65+$ & 15 & 20.5 & 40 & 24.4 & 55 & 23.2 \\
\hline$p^{\mathrm{b}}$ & \multicolumn{6}{|c|}{0.727} \\
\hline \multicolumn{7}{|l|}{ Marital Status } \\
\hline Married & 58 & 79.5 & 124 & 75.6 & 182 & 76.8 \\
\hline Single & 5 & 6.8 & 16 & 9.8 & 21 & 8.9 \\
\hline Widow/divorced & 10 & 13.7 & 24 & 14.6 & 34 & 14.3 \\
\hline$p^{\mathrm{b}}$ & \multicolumn{6}{|c|}{0.713} \\
\hline \multicolumn{7}{|l|}{ Educational status } \\
\hline Primary school and under & 63 & 85.1 & 147 & 89.6 & 210 & 88.6 \\
\hline High school and above & 10 & 14.9 & 17 & 10.4 & 27 & 11.4 \\
\hline$p^{\mathrm{b}}$ & \multicolumn{6}{|c|}{0.456} \\
\hline Total & 73 & $30.8^{c}$ & 164 & $69.2^{\mathrm{c}}$ & 237 & 100.0 \\
\hline
\end{tabular}

"Do you notice any abnormality, due to the water you use in the region?" $66.2 \%$ replied positively. Problems connected to the drinking water were detected in $52.1 \%$ of the participants living in the Kirazli region and in $72.4 \%$ of those living in the Ciplak-Halileli region, for whom values were found to be statistically significant $(p<0.05)$. Whereas $71.1 \%$ of those living in the Kirazli region reported change in color (yellow) due to corrosion and 21.1\% reported puncture in their saucepans, due to the water used, $90 \%$ of the people living in the Ciplak-Halileli region observed calcification.

Despite the differences in Al levels in their water supplies, no statistically significant difference was detected between the $\mathrm{Al}$, vitamin $\mathrm{B}_{12}$, and TSH levels of the participants living in the two regions $(p>0.05)$. However, a significant difference was detected between their serum folic acid values $(p<0.05)$. Whereas folic acid levels were detected to be 2.9 and lower in $15.1 \%$ of those living in the Kirazli region, the same levels were found as $2.4 \%$ in the Ciplak-Halileli region (Table 3). Serum Al levels were found to be nearly normal in both regions, with levels of $89 \%$ and $86 \%$ in the Kirazli and Ciplak-Halileli regions, respectively. Vitamin $\mathrm{B}_{12}$ levels were found to be lower than $249 \mathrm{pg} / \mathrm{dL}$ in $60.3 \%$ of those living in the Kirazli region and $70.7 \%$ of those living in the Ciplak-Halileli region. 
Table 3 Serum Al, vitamin $\mathrm{B}_{12}$, folic acid, and TSH levels in the study area

\begin{tabular}{|c|c|c|c|c|}
\hline & \multicolumn{2}{|c|}{ Kirazli } & \multicolumn{2}{|c|}{ Ciplak-Halileli } \\
\hline & $n$ & $\%^{\mathrm{a}}$ & $n$ & $\%^{\mathrm{a}}$ \\
\hline Aluminum normal $(1.0-14.0 \mu \mathrm{g} / \mathrm{l})$ & 65 & 89.0 & 141 & 86.0 \\
\hline High $(>14.0 \mu \mathrm{g} / \mathrm{l})$ & 8 & 11.0 & 23 & 14.0 \\
\hline$p^{\mathrm{b}}$ & \multicolumn{4}{|c|}{0.518} \\
\hline \multicolumn{5}{|l|}{ Vitamin $\mathrm{B}_{12}$} \\
\hline $249 \mathrm{pg} / \mathrm{dl}$ or less & 44 & 60.3 & 116 & 70.7 \\
\hline $250 \mathrm{pg} / \mathrm{dl}$ or higher & 29 & 39.7 & 48 & 29.3 \\
\hline$p^{\mathrm{b}}$ & \multicolumn{4}{|c|}{0.113} \\
\hline \multicolumn{5}{|l|}{ Folic acid } \\
\hline 2.9 or less & 11 & 15.1 & 4 & 2.4 \\
\hline $3.0-17$ & 62 & 84.9 & 156 & 95.1 \\
\hline $17.0+$ & 0 & 0.0 & 4 & 2.4 \\
\hline$p^{\mathrm{b}}$ & \multicolumn{4}{|c|}{0.001} \\
\hline \multicolumn{5}{|l|}{ TSH } \\
\hline 0.39 or less & 8 & 11.0 & 18 & 11.0 \\
\hline $0.4-4.0$ & 63 & 86.3 & 139 & 84.8 \\
\hline $4.01+$ & 2 & 2.7 & 7 & 4.3 \\
\hline$p^{\mathrm{b}}$ & \multicolumn{4}{|c|}{0.850} \\
\hline
\end{tabular}

Diagnosed chronic diseases were detected in $37.6 \%$ of the subjects and their distribution revealed that $22.4 \%$ had hypertension, $9.7 \%$ had diabetes mellitus, $6.8 \%$ had rheumatic diseases and $5.5 \%$ had renal diseases. No statistically significant difference was detected between the two regions regarding the detection of chronic diseases $(p>0.05)$.

The relationship between the MMSE scores and serum $\mathrm{Al}$, TSH, vitamin $\mathrm{B}_{12}$, and folic acid levels of the subjects was evaluated using Pearson correlation analysis. Only a weak positive correlation was detected between the MMSE scores and the Al levels $(r=0.144 ; p=0.03)$. When the groups with vitamin $\mathrm{B}_{12}$ levels under or over $249 \mathrm{pg} / \mathrm{dL}$ were evaluated separately, a significant correlation was detected between the MMSE scores and serum Al levels; these results were, respectively, $r=0.152, p=0.057$ and $r=0.129, p=0.264$.

When the distribution of the MMSE scores between Kirazli and Ciplak-Halileli regions was studied, no statistically significant difference was detected $(p>0.05)$. However, it is worth noting that the MMSE scores were lower than 22 in $33.3 \%$ of those living in the Kirazll region and in $31.3 \%$ of those living in the Ciplak-Halileli region.

When the distribution of the MMSE scores of the subjects was evaluated according to their primary demographic characteristics (Table 4), it was seen that the MMSE scores of 23 and higher were mostly detected in the males, in the young population, in those having an
Table 4 Mini-Mental State Examination score

\begin{tabular}{|c|c|c|c|c|}
\hline \multirow[t]{2}{*}{ MMSE score } & \multicolumn{2}{|c|}{ Kirazli } & \multicolumn{2}{|c|}{ Ciplak-Halileli } \\
\hline & $n$ & $\%^{a}$ & $n$ & $\%^{a}$ \\
\hline 22 or less & 24 & 33.3 & 51 & 31.3 \\
\hline 23 or higher & 48 & 66.7 & 112 & 68.7 \\
\hline Total & 72 & $30.6^{\mathrm{b}}$ & 163 & $69.4^{\mathrm{b}}$ \\
\hline$p^{\mathrm{c}}$ & \multicolumn{4}{|c|}{0.757} \\
\hline
\end{tabular}

${ }^{a}$ Column percentage

b Row percentage

${ }^{c}$ Chi-square test

Table 5 Neuropathy in the history and examination

\begin{tabular}{|c|c|c|c|c|}
\hline & \multicolumn{2}{|c|}{ Kirazli } & \multicolumn{2}{|c|}{ Ciplak-Halileli } \\
\hline & $n$ & $\%^{\mathrm{a}}$ & $n$ & $\%^{\mathrm{a}}$ \\
\hline \multicolumn{5}{|c|}{ Neuropathy in the history } \\
\hline Present & 29 & 40.3 & 43 & 26.2 \\
\hline Absent & 43 & 59.7 & 121 & 73.8 \\
\hline Total & 72 & $26.2^{\mathrm{b}}$ & 164 & $69.5^{\mathrm{b}}$ \\
\hline$p^{\mathrm{c}}$ & 0.03 & & & \\
\hline \multicolumn{5}{|c|}{ Neuropathy in the examination } \\
\hline Present & 14 & 19.2 & 32 & 19.3 \\
\hline Absent & 59 & 80.8 & 132 & 80.7 \\
\hline Total & 73 & $30.8^{\mathrm{b}}$ & 164 & $69.2^{\mathrm{b}}$ \\
\hline$p^{\mathrm{c}}$ & 0.952 & & & \\
\hline
\end{tabular}

${ }^{a}$ Column percentage

b Row percentage

c Chi-square test

education level of high school and over, in those smoking, and in those having no chronic disease (hypertension and diabetes mellitus), and this situation was found to be significant $(p<0.05)$.

No statistically significant difference was found between the two regions regarding the physical examination findings $(p>0.05)$. However, detection of neuropathy history was relatively higher in the Kirazli region, creating a statistically significant difference $(p<0.05)$ (Table 5).

\section{Discussion}

The potential of environmental factors affecting people's health is a well-known fact since the time of Hippocrates. Today, it is scientifically accepted that many environmental factors affect human health. The potential of $\mathrm{Al}$, which is found in large amounts in the nature, negatively affecting people's health caught researchers' attention, thanks to the patients having chronic renal deficiency undergoing dialysis treatment (Flaten 2001; Onur 1997). 
Results of the experimental studies demonstrating the powerful neurotoxic potential of $\mathrm{Al}$ indicated the kind of effect it would have if taken with foods and drinking water over many years. Epidemiological studies suggested that there could be a relationship between the Al levels in drinking waters and AD (Molloy et al. 2007). Unfortunately, the backgrounds of these studies do not date back to quite early times. However, two parallel studies performed in Norway in 1986 might provide an example (Flaten 2001). In these studies, it was observed that the rate of mortality due to dementia was higher in the regions with drinking waters containing high levels of Al (Flaten 2001).

The current study was planned after detecting high levels of $\mathrm{Al}$ in the water resources of the Kirazli region. The primary intention was to detect the effects caused by elevated Al levels on local people. Detailed investigations were performed regarding the quality of water resources in the study area through the concentrations of some elements such as Al, As, Se, F, and Pb (Baba and Deniz 2008; Baba et al. 2008). Based on the results of this water quality monitoring program, it was detected that the Al concentration is relatively higher in the waters characterized by acidic content in the Kirazli region (Table 2). The maximum $\mathrm{Al}$ concentration value to be found in the drinking waters is restricted to $0.2 \mathrm{ppm}$ by WHO, the US EPA, and the Turkish Ministry of Health (TC The Official Gazette 2005; WHO 2008). The raw water source was located in the middle of the Kirazli region, which had acidic characteristics and was rich in $\mathrm{Al}$, and is known to be extensively used for drinking water by the local people and by the people coming from the other provinces.

No statistically significant difference was detected between the serum Al levels in the regions examined in this study. Al's primary pathway in people is thorough the digestive system. On the other hand, water has the highest potential to carry Al into people's bodies. The amount of $\mathrm{Al}$ directly passing into the blood from the digestive system is $<1 \%$ (Flaten 2001). Al is found in small amounts in the serum, after being taken via the digestive system in normal ways (1-2 $\mu \mathrm{g} / \mathrm{l})$ (Flaten 2001; Ganrot 1986; Krewski et al. 2007). A large amount of $\mathrm{Al}$ is stored in various tissues such as bones and lungs. In healthy people, $\mathrm{Al}$ is normally discharged from the body through the kidneys (Flaten 2001; Ganrot 1986; Krewski et al. 2007). The serum Al level might increase up to $30 \mu \mathrm{g} / \mathrm{l}$ in the dialysis patients having chronic renal deficiency. In dialysis patients with chronic renal deficiency, high $\mathrm{Al}$ levels may result in problems such as osteomalacia and dialysis encephalopathy or dementia (Flaten 2001; Ganrot 1986; Krewski et al. 2007).

It was an expected finding that there was no remarkable increase in the $\mathrm{Al}$ levels in the study groups, excluding those with chronic renal deficiency and digestive system diseases requiring the use of antiacids. In our group, there were no chronic renal deficiency patients receiving dialysis treatment. Twenty-three people $(9.7 \%)$ having gastritis or an ulcer did not provide any input regarding regular antiacid usage. Therefore, no difference was detected between the two study groups in their serum Al levels.

The risks connected to chronic Al exposure should not be disregarded. The development of a disease due to accumulation of $\mathrm{Al}$ in any organ of the body requires a continuous process lasting for many years. It has been known since 1960s that chronic Al exposure causes neuropsychological damage, encephalopathy and connected attacks, incoordination, intentional tremor, and cognitive deficits (Molloy et al. 2007; Polizzi et al. 2002). This suggests that chronic Al exposure via drinking water might constitute a significant risk factor for mild cognitive impairment (MCI), dementia, and other neurological diseases, which are not considered a serious medical or psychiatric situation in the elderly, due to having mild memory and cognitive impairments but no dementia (Flaten 2001; Petersen et al. 1999). MCI can be a prodromal phase of dementia and approximately $12 \%$ of the patients having MCI also develop dementia (Petersen et al. 1999, 2001); this rate increases up to $19.9 \%$ within 5 years (Morris et al. 2001). In their observational study carried out between 1988 and 2003, Rondeau et al. (2009) demonstrated that cognitive disorders and dementia are detected in higher rates in the people living in regions with drinking water containing high levels of Al. Moreover, in another study published in 1995, it was reported that there could be a direct relationship between the amount of $\mathrm{Al}$ existing in the drinking water and dementia (Nieboer et al. 1995; Polizzi et al. 2002). However, it is not easy to define this relationship clearly, because diseases like dementia and AD have multifactorial etiologies and often there is multiple complexity factors involved in this kind of study (Nieboer et al. 1995).

In terms of the MMSE score, the findings obtained in this study indicate a cognitive damage in one-third of the subjects living in the study regions. However, no statistically significant difference was detected between the Kirazlı region, which had higher amounts of $\mathrm{Al}$ in the drinking water, and the Ciplak-Halileli region, which had normal Al levels (Table 4). This is an interesting finding. Low vitamin $\mathrm{B}_{12}$ levels were also observed in the people participating from the both regions. On the other hand, folic acid levels were found to be higher in the people living in the Kirazli region compared to those living in the Ciplak-Halileli region (Table 3 ). In addition, the mean age of the subjects was 51.6 and $88 \%$ of them had an education level of primary school and less. All of the aforementioned factors constitute a risk for negatively affecting the MMSE scores. The findings regarding the low vitamin $\mathrm{B}_{12}$ levels 
detected in the both regions is especially interesting as a confusing factor. A weakness in the cognitive status was detected in the people living in both regions. However, this cannot be associated with $\mathrm{Al}$ concentration results, due to the influence of the confusing factors. The most objective way of determining the relationship between Al concentration and the cognitive status is planning an observational study with a cohort group, in which the influence of the confusing factors is minimized. However, this kind of study requires many years of observation before obtaining results. Similar studies are available in the literature. In the 8-year- and 15-year-duration observational studies carried out by Rondeau et al. in 2000 and 2009, AD was detected at a higher rate in those consuming drinking waters with an Al level over $0.1 \mathrm{mg} / \mathrm{l}$, according to the evaluation performed by using the MMSE (Rondeau et al. 2000, 2009). The studies recommended conducting new observational surveys in order to be able to determine causes and effects of high $\mathrm{Al}$ levels found locally in the region on people's health.

Today, the neurotoxic effects connected to Al are known relatively better. Experiments performed on animals and studies carried out on postmortem and dialysis patients largely revealed some detrimental effects on people caused by the existence of $\mathrm{Al}$ concentrations in the drinking water. However, the data obtained from epidemiological studies based on drinking water are limited and controversial. In this paper, some examples from various studies in support of the detrimental effects caused by $\mathrm{Al}$ concentrations have been provided earlier. For example, Solfrizzi et al. (2003) reported a relationship between $\mathrm{Al}$ concentration and dementia; others did not report such a relationship. In other studies, the difficulty regarding the detection of the relationship between $\mathrm{Al}$ concentration and $\mathrm{AD}$ in epidemiological studies is highlighted. It is also reported that the potential of $\mathrm{Al}$ existence found in some foods and in medicines, as well as in drinking water, could be a confusing factor (Rogers and Simon 1999). In 2001, Flatten performed an analysis of the studies investigating the relationship between $\mathrm{Al}$ levels found in the drinking water versus $\mathrm{AD}$ and dementia diseases seen in the local people. For example; in the study carried out by McLachlan et al., the $\mathrm{Al}$ concentration found in the drinking water was detected to be a significant risk factor for AD (Flaten 2001; McLachlan et al. 1996). On the other hand, no relationship was detected in the study performed by Taylor et al. (Flaten 2001; Taylor et al. 1995).

Studies by Vogt (1986) demonstrated that there was a dose-response relationship between the Al concentration found in the drinking water and dementia. In the study performed by Wood et al. (1988), mental test scores of those consuming drinking water containing high Al levels were found to be relatively lower. Martyn et al. (1997) compared two regions in which the $\mathrm{Al}$ level of the drinking water was $0.11 \mathrm{mg} / \mathrm{l}$ in one and less than $0.01 \mathrm{mg} / \mathrm{dl}$ in the other; they reported that the relative $\mathrm{AD}$ risk was 1.5 times higher (Flaten 2001).

Wettstein et al. (1991) did not find any difference in terms of cognitive damage in their study group consisting of people living in Switzerland for 15 years, whose ages varied between 80 and 85 . These participants were divided into two groups, based on their drinking water $\mathrm{Al}$ concentration of $0.10 \mathrm{mg} / \mathrm{l}$ and $<0.01 \mathrm{mg} / \mathrm{l}$. These results are different than that of other epidemiological studies. However, the level of $0.10 \mathrm{mg} / \mathrm{l}$, which is the highest $\mathrm{Al}$ level in the study, is not actually a very high level. In addition, drinking water comes from two different supplies. Due to the differences in the composition of Al level, its bioavailability might differ between different drinking water sources. In this study, the bioavailability of the Al level can be lower in the water representing the high Al level.

Another result observed in this study is the detection of a history of neuropathy. Whereas neuropathy was detected in the physical examination of $19 \%$ of the participants, no statistically significant difference was found between them (Table 5). However, a difference was detected in the neuropathy history location wise (Table 5). A history of neuropathy was detected in $40 \%$ of the participants living in the Kirazli region and in $26 \%$ of those living in the CiplakHalileli region.

The neurotoxic effects of Al levels suggest a neuropathic effect, in addition to cognitive effects and dementia. Uremic neuropathy, which is observed in patients with chronic renal deficiency, was defined by Kussmaul for the first time in 1863 (Burn and Bates 1998). The main neurological manifestations of uremia include encephalopathy, neuropathy that can affect cranial, peripheral, and autonomic nerves, and proximal myopathy. With the active administration of dialysis in uremic patients, complications connected to dialysis also started to be seen. Chronic dialysis is associated with three main neurological syndromes:

1. The disequilibrium syndrome, usually seen in the first few hemodialysis sessions and prevented by starting dialysis with a low dose and progressively increasing the dialysis dose in subsequent dialysis sessions.

2. Dialysis dementia, which results from $\mathrm{Al}$ overloading and is prevented by reducing exposure of the dialysis patients to $\mathrm{Al}$.

3. Nerve entrapment, particularly carpal tunnel syndrome, which is caused by $\beta_{2}$-microglobulin amyloidosis and might be prevented by the use of high-flux dialyzers, which provide relatively high clearance for $\beta_{2}$-microglobulin or by daily hemodialysis (Tzamaloukas and Agaba 2004). 
The pathogenesis of neuropathy and encephalopathy in patients with renal failure remains unknown. Possible factors include $\mathrm{Al}$ intoxication, in particular (Sperschneider et al. 1982). The relationship between Al level and neuropathy is mostly backed up by the data obtained from uremic patients undergoing dialysis treatment. However, uremia alone can cause neuropathy in these patients, making it difficult to detect exclusive effects of Al level. As a result, a multifactorial interaction is effective in the formation of neuropathy. In the regions examined, it was observed that there was a vitamin $\mathrm{B}_{12}$ deficiency in both regions, whereas folic acid deficiency, hypertension $(22 \%)$, and diabetes $(10 \%)$ were detected in the Kirazli region. All of the aforementioned factors stand out as a complexity factor for the neuropathy history. Both regions have similarities in terms of the other variations, except for the folic acid levels. This indicates that the reason underlying the liability of neuropathy in the Kirazli region can be chronic $\mathrm{Al}$ exposure. More objective evaluations can be made with additional observational surveys.

Although different results are reported in different epidemiological studies, the data at hand suggest that the $\mathrm{Al}$ concentration found in high rates in the drinking water might have negative effects on people's health. This study does not present objective evidence demonstrating that the people living in the Kirazli region were affected by the Al level. However, findings regarding the high rate of cognitive disorders found in the people living in the region and neuropathy history, which was detected as higher in the Kirazli region, increase our suspicions for being caused by the existence of $\mathrm{Al}$ in the drinking water, in spite of the high rate of vitamin $B_{12}$ deficiency. The way to justify these suspicions based on powerful evidence is by conducting additional observational studies.

\section{Conclusions}

Evaluation of the data obtained in the scope of this study indicates that further monitoring studies should be planned to allow more objective observations of the problems to be made, especially the existence of $\mathrm{Al}$ in the drinking water. Another interesting point to consider is that the people living in the Kirazli region still continue consuming water containing high Al concentrations. In general, there are purification technologies regarding the elimination of $\mathrm{Al}$ in the water supplies. However, purification technologies require electrical power. People living in the region cannot use such techniques due to economic reasons. The carbonated water within the alluvium deposits found in the peninsula could be used as a source of water for the region's population to this end.
It is important to monitor, for drinking purposes, the quality of water exposed at rock-water interactions in alteration zones. This kind of water have been seen in many countries. This water has higher acidity and more trace element concentrations. The levels of these elements are found to exceed the maximum allowable limits set by national and international standards for the drinking water quality. This finding demonstrates the necessity for conducting detailed research on human health effects of consuming such waters.

Acknowledgments The authors express their gratitude to the Turkish Academy of Sciences (TÜBA) and Scientific and Technical Research Council of Turkey (TÜBITAK) for providing financial aid. We thank Isfendiyar Egeli and Orhan Gunduz, who checked the English of this article.

\section{References}

Baba A, Deniz O (2008) Potential, determination of applicability and evaluation of environmental effects of geothermal source in the Biga Peninsula. CAYDAG-Project number 104Y082. TÜBİTAK, Ankara

Baba A, Gunduz O (2009) Effect of alteration zones on water quality: a case study from Biga Peninsula, Turkey. Arch Environ Contam Toxicol. doi:10.1007/s00244-009-9406-8

Baba A, Save D, Gunduz O, Gurdal G, Bozcu M, Sulun S, Ozcan H (2008) The assessment of mining activities in Can Coal district from medical geology perspective. CAYDAG-Project number 106Y041, TÜBİTAK, Ankara

Burn DJ, Bates D (1998) Neurology and the kidney. J Neurol Neurosurg Psychiatry 65:810-821

Flaten TP (2001) Aluminum as a risk factor in Alzheimer's disease, with emphasis on drinking water. Brain Res Bull 55(2):187-196

Ganrot PO (1986) Metabolism and possible health effects of aluminum. Environ Health Perspect 65:363-441

Güngen C, Ertan T, Eker E, Yaşar R, Engin F (2002) Validity and reliability of Standardized Mini Mental Test in the slight dementia diagnosis in the Turkish society. Turkish Psychiatry 13(4):273-281

Krewski D, Yokel RA, Nieboer E, Borchelt D, Cohen J, Harry J (2007) Human health risk assessment for aluminum, aluminum oxide, and aluminum hydroxide. J Toxicol Environ Health B Crit Rev 10:1-269

Martyn CN, Coggon DN, Inskip H, Lacey RF, Young WF (1997) Aluminum concentrations in drinking water and risk of Alzheimer's disease. Epidemiology 8:281-286

McLachlan DRC, Bergeron C, Smith JE, Boomer D, Rifat SL (1996) Risk for neuropathologically confirmed Alzheimer's disease and residual aluminum in municipal drinking water employing weighted residential histories. Neurology 46:401-405

Meyer-Baron M, Schäper M, Knapp G, van Thriel C (2007) Occupational aluminum exposure: evidence in support of its neurobehavioral impact. Neurotoxicology 28(6):1068-1078

Molloy DW, Standish TI, Nieboer E, Turnbull JD, Smith SD, Dubois $S$ (2007) Effects of acute exposure to aluminum on cognition in humans. J Toxicol Environ Health A 70:2011-2019

Morris JC, Storandt M, Miller P, McKeel DW, Price JL, Rubin EH, Berg LM (2001) Cognitive impairment represents early-stage Alzhimer disease. Arch Neurol 58:397-405 
MTA (2002) Geological map of Turkey, scale 1:500.000. General Directorate of Mineral Research and Exploration (MTA), Ankara

Nieboer E, Gibson BL, Oxman AD, Kramer JR (1995) Health effects of aluminum: a critical review with emphasis on aluminum in drinking water. Environ Rev 3(1):29-81

Nordberg G (1993) Metals: chemical properties and toxicity, aluminum. In: Stellman JM (ed) Encyclopedia of occupational health and safety, vol III, 4th edn. International Labour Office, Geneva, p 63.2

Onur E (1997) Evaluation of aluminium toxicity the point of view of quality control. Off J Turkish Nephrol Assoc 1-2:74-79 (in Turkish)

Oteiza PI, Mackenzie GG, Verstraeten SV (2004) Metals in neurodegeneration: involvement of oxidants and oxidant-sensitive transcription factors. Mol Aspects Med 25(1-2):103-115

Petersen RC, Smith GE, Waring SC, Ivnik RJ, Tangalos EG, Kokmen E (1999) Mild cognitive impairment: clinical characterization and outcome. Arch Neurol 56:303-308

Petersen RC, Doody R, Kurz A, Mohs RC, Morris JC, Rabins PV (2001) Current concepts in mild cognitive decline. Arch Neurol 58:1985-1992

Polizzi S, Pira E, Ferrara M, Bugiani M, Papaleo A, Albera R, Palmi $S$ (2002) Neurotoxic effects of aluminum among foundry workers and Alzheimer's disease. Neurotoxicology 23:761-774

Rogers MAM, Simon DG (1999) A preliminary study of dietary aluminium intake and risk of Alzheimer's disease. Age Ageing 28:205-209

Rondeau V, Commenges D, Jacqmin-Gadda H, Dartigues JF (2000) Relation between aluminum concentrations in drinking water and Alzheimer's disease: an 8-year follow-up study. Am J Epidemiol 152(1):59-66

Rondeau V, Jacqmin-Gadda H, Commenges D, Helmer C, Dartigues JF (2009) Aluminum and silica in drinking water and the risk of Alzheimer's disease or cognitive decline: findings from 15-year follow-up of the PAQUID cohort. Am J Epidemiol 169(4):489_ 496
Solfrizzi V, Panza F, Capurso A (2003) The role of diet in cognitive decline. J Neural Transm 110:95-110

Sperschneider H, Spustova V, Stein G, Dzurik R (1982) Middle molecular weight substances in the cerebrospinal fluid of uremic patients. Clin Nephrol 17(6):298-302

Taylor GA, Newens AJ, Edwardson JA, Kay DWK, Forster DP (1995) Alzheimer's disease and the relationship between silicon and aluminum in water supplies in northern England. $\mathbf{J}$ Epidemiol Community Health 49:323-328

TC: The Official Gazette (2005) İnsani tüketim amaçlı sular hakkındaki yönetmelik, 17 Şubat 2005 Perşembe, Sayı:25730, 2005. Available from http://rega.basbakanlik.gov.tr/\# (in Turkish)

TSI (2007) Adrese dayalı nüfus kayıt sistemi nüfus sayımı sonuçları, Turkish Statistical Institute.Available from http://tuikapp.tuik. gov.tr/adnksdagitapp/adnks.zul (in Turkish)

Tzamaloukas AH, Agaba EI (2004) Neurological manifestations of uraemia and chronic dialysis. Niger J Med 13(2):98-105

Vogt T (1986) Water quality and health: study of a possible relation between aluminium in drinking water and dementia. Sosiale og Økonomiske Studier No. 61. Central Bureau of Statistics of Norway, Oslo

Wettstein A, Aeppli J, Gautschi K, Peters M (1991) Failure to find a relationship between mnestic skills of octogenarians and aluminum in drinking water. Int Arch Occup Environ Health 63(2):97-103

WHO (2008) Guidelines for drinking-water quality, vol 1, 3rd edn. Incorporating the first and second addenda. WHO, Geneva

Wood DJ, Cooper C, Stevens J, Edwardson J (1988) Bone mass and dementia in hip fracture patients from areas with different aluminum concentrations in water supplies. Age Ageing 17:415419

Young DS, Bermes EW (1999) Specimen collection and processing: sources of biological variation. In: Burtin CA, Ashwood ER (eds) Tietz textbook of clinical chemistry, 3rd edn. W.B. Saunders, Philadelphia, pp 42-44 